DOI 10.37882/2223-2982.2020.06.09

\title{
ОСНОВНЫЕ ПОДХОДЫ В БОРЬБЕ С ЭКСТРЕМИЗМОМ И ТЕРРОРИЗМОМ В РОССИЙСКОЙ ФЕДЕРАЦИИ ПОСЛЕ СОБЫТИЙ АВГУСТА - СЕНТЯБРЯ 1999 ГОДА В РЕСПУБЛИКЕ ДАГЕСТАН
}

\section{MAIN APPROACHES IN THE FIGHT AGAINST EXTREMISM AND TERRORISM IN THE RUSSIAN FEDERATION AFTER THE EVENTS OF AUGUST - SEPTEMBER 1999 IN THE REPUBLIC OF DAGESTAN}

\section{F. Dalgat}

Summary: The article is devoted to the analysis of the main ways and practical ways of the struggle of the power structures and state authorities of the Russian Federation against extremism and terrorism in the Republic of Dagestan after the invasion of international gangs on its territory in August-September 1999.

Keywords: international gangs, invasion, Republic of Dagestan, extremism, terrorism, countermeasures, state authorities.

\author{
Далгат Фатима Магомедовна \\ К.и.н., доцент, ФГБОУ ВО «Дагестанский \\ государственный университет» \\ dalgat63@mail.ru
}

Аннотация: Статья посвящена анализу основных путей и практических способов борьбы силовых структур и государственных органов власти Российской Федерации с экстремизмом и терроризмом в Республике Дагестан после вторжения на ее территорию в августе-сентябре 1999 г. международных бандформирований.

Ключевые слова: международные бандформирования, вторжение, Республика Дагестан, экстремизм, терроризм, меры противодействия, государственные органы власти.
И сториографический анализ разработки данной проблемы свидетельствует о том, что ею занимались специалисты в разных областях науки: историки, правоведы, политологи, социологи, военные специалисты. Зачастую их выводы по указанной проблеме не совпадают, что вызывает необходимость ее дальнейшего изучения.

В 2019 г. в Дагестане отметили двадцатилетие разгрома вооруженных международных экстремистских отрядов, вторгшихся в августе-сентябре 1999 года под руководством Ш. Басаева и Хаттаба на дагестанские села Ботлихского, Цумадинского, Буйнакского и Новолакского районов с территории соседней республики Ичкерия. Специалисты квалифицируют это вторжение как диверсионно-террористическую операцию, представляющую апогей террористической деятельности конца 90-х гг. в России, которая привела к крупномасштабной дестабилизации обстановки в Дагестане [1, с. 41].

К концу 90-хгг. религиозно-политический экстремизм, замешанный на псевдоисламской идеологии, стал серьезной проблемой российского и мирового сообщества. Кровавые деяния экстремистских организаций, проповедующих терроризм, как наиболее опасной формы экстремизма, захлестнули территории с компактным проживанием этнических мусульман. Не стал исключе- нием и Северный Кавказ, на протяжении более двадцати лет сотрясаемый войнами, социальной нестабильностью и террористическими актами. Военные действия на территории соседней с Дагестаном Республики.

Ичкерия и последовавшая вслед за этим радикализация чеченского общества, отразилась и на Дагестане. Сюда стали проникать экстремистские организации, сумевшие создать к 1998-1999 гг. в Буйнакском районе республики «отдельную исламскую территорию», так называемую Кадарскую зону, неподконтрольную властям. Она стала движущей силой вторжения в Дагестан вооруженных экстремистов и басаевско-хаттабовских международных бандформирований. Вторжение имело далеко идущие цели, в том числе, свержение конституционного строя в Республике Дагестан, присоединение ее территории к Чечне и создание единого исламского государства, отделение северокавказских народов от России, создание подобной ситуации в других регионах России. Однако эта вооруженная интервенция против одного из субъектов РФ, так как ядро бандформирований составляли иностранные наемники, привела к консолидации не только народностей Дагестана, но и всех россиян. Более того, эти события стали переломным моментом в истории государственности Российской Федерации, началом её возрождения, поскольку вторжение в Даге- 
стан, по сути, поставило вопрос, быть или не быть России как государству.

В трудные дни сентября-августа 1999 г. население Дагестана инициировало создание добровольных отрядов самообороны, народного ополчения, оказало действенную помощь российским войскам и органам правопорядка в отражении агрессии. 16 сентября 1999 года после освобождения территории Дагестана от вооруженных формирований Народное Собрание Республики Дагестан приняло Закон «О запрете ваххабитской и иной экстремистской деятельности на территории Республики Дагестан» [2]. Закон указывал, что деятельность экстремистов была направлена на насильственное изменение конституционного строя, подрыв безопасности государства и общественного порядка, создание вооруженных формирований, пропаганду войны, разжигание национальной, расовой и религиозной розни, посягала на права и свободы граждан, побуждала граждан к отказу от исполнения установленных законом гражданских обязанностей и совершению иных противоправных действий. Законом также запрещалось направлять граждан Республики Дагестан за границу для получения религиозного образования без согласования государственного органа по делам религий РД. Отдельно оговаривалось, что обучение в религиозных образовательных учреждениях на территории республики следует осуществлять строго по учебным программам, утвержденным соответствующими структурами. Кроме того, согласно новому закону, все религиозные организации, функционировавшие в республике, подлежали перерегистрации в трехмесячный срок.

Таким образом, в Республике Дагестан, хоть и несколько запоздало, но была создана правовая основа для борьбы с экстремистскими организациями. Более того, в указанном законе понятия ваххабизм и экстремизм фактически были приравнены друг другу и не оставляли возможности для разного рода толкований, что имело положительное значение в борьбе с подобного рода негативными социальными проявлениями.

Днем ранее, 15 сентября, Государственная Дума Федерального собрания РФ приняла постановление «О ситуации в Республике Дагестан и первоочередных мерах по обеспечению национальной безопасности Российской Федерации и борьбе с терроризмом» [3] , осуждающее вторжение бандформирований в Республику Дагестан. В нем высоко оценивались действия группировки федеральных сил и жителей Дагестана, вставших на защиту независимости и территориальной целостности России. В документе российские парламентарии указывали на причины северокавказского кризиса, среди которых названы серьезные просчеты Президента РФ, Федерального Собрания РФ при формировании и реализации в этом регионе стратегии национальной политики, кото- рая консервировала многолетний комплекс проблем, не способствовала их постепенному и бескровному разрешению. Документ содержал также предложения на имя Президента России Б. Ельцина об издании указа, который позволил бы группировке федеральных сил уничтожать незаконные вооруженные формирования на Северном Кавказе, повысить эффективность руководства действиями группировки федеральных сил в РД, а также принять дополнительные меры по укреплению государственной границы в кавказском регионе. Депутаты предложили Правительству России усилить работу спецслужб и правоохранительных органов по борьбе с терроризмом и организованной преступностью [3].

Председатель правительства РФ В. Путин в своем выступлении 15 сентября 1999 г. перед депутатами Государственной Думы произнес слова, которые можно считать стратегией Центра на Северном Кавказе: «Хотел бы подчеркнуть: быстро можно победить только самих бандитов, но не источники возникновения терроризма. Я считаю, что задача номер один здесь - это защита населения от бандитов. Их выявление, пресечение и предание суду. Организация необходимых мероприятий по обеспечению личной безопасности граждан. В Москве и других городах, в Дагестане - везде, где такая опасность может возникнуть. Задача номер два - нахождение и предупреждение возникновения очагов конфликтов. Ликвидация самих баз подготовки террористов, лишение их источников и кадровой подпитки как изнутри России, так и из-за рубежа. И, наконец, задача номер три. Лечение «вируса войны» на Северном Кавказе путем применения целого комплекса мер по стабилизации социально-экономического и политического положения в этом регионе. Сегодня чрезвычайно важно не допустить, чтобы в конфликт оказались втянуты большие массы населения. А ведь именно на это ориентирована тактика бандитов. Они специально проводят жесткие операции, ожидая, что ответные жесткие действия федеральных сил вызовут недовольство местного населения, где эти операции проводятся. Другое немаловажное обстоятельство: резкое изменение психологии населения в ситуации длительного конфликта...» [4, с. 2].

После этого заявления будущего президента РФ стали ясны основные направления действия федеральных сил по подавлению террористических организаций на Кавказе и возвращению региона в мирное русло.

В 2000 году специальные службы РФ - Федеральная служба безопасности, Федеральная служба налоговой полиции, Министерство внутренних дел РФ - развернули масштабную работу по пресечению каналов финансирования незаконных вооруженных формирований со стороны международных религиозных благотворительных организаций, международных радикальных организаций и заинтересованных в дестабилизации региона 
государств. Эта работа началась с оперативно - розыскных мероприятий в финансово-кредитной сфере, а также комплексных проверок структур и лиц, подозреваемых в финансировании экстремистских организаций. Как указывают исследователи проблемы, финансирование террористических организаций на Северном Кавказе осуществлял лидер международной террористической организации «Аль-Каиды» Усама бен Ладен, отправивший арабскому полевому командиру Хаттабу 5,5 млн. долларов [5]. Переправка денежных средств в Дагестан и Чечню осуществлялась курьерами, которые проникали сюда через сопредельные государства Грузию и Азербайджан. В Баку находились гражданин Судана Аль-Хайри Мухди Аль-Хаир Судани и араб Абу Якуб (финансист Хаттаба). Последний доставил около 200 тыс. долл. США, выделенных «исламским фондом развития» для организации вооруженного сопротивления федеральным силам в Чечне.

Помимо этого, финансирование террористической операции в Дагестане осуществляли неправительственные катарские, кувейтские, ливийские, турецкие и некоторые другие исламистские фонды.

Важным звеном в финансовых потоках из Ближнего Востока на Северный Кавказ был активный участник салафитского движения Багаутдин Кебедов, выходец из Дагестана, получавший помощь от таких организаций, созданных ближневосточными шейхами, как Фонд «АльХарамайн», Всемирная ассамблея исламской молодежи, организации «Аль-Игаса аль-исламийя», «Тайба», а также ряд других подобных организаций.

Учитывая данные обстоятельства, первым делом были закрыты российские представительства вспомогательных террористических структур - фондов «АльХарамайн» (Судан), «Аль-Игаса» (Саудовская Аравия), «Таблиг» (Пакистан). Через эти религиозные организации осуществлялось финансирование ваххабитских организаций на Северном Кавказе. В Дагестане эти благотворители помимо финансирования ваххабизма проводили разведывательные и подрывные акции.

Серьезный удар был нанесен по криминальному бизнесу, осуществлявшему финансирование политических и религиозных экстремистов. В первую очередь, это касалось незаконного нефтегазового промысла. Так, в 1998 г. доходы от незаконной переработки нефти в Чечне оценивались в 3 млн. долл. ежемесячно [6, с. 312]. Параллельно с этим был нанесен чувствительный удар по криминальным доходам, связанных с экстремистами лиц, промышлявших киднеппингом, рэкетом, контрабандой оружия и наркотиков, финансовыми махинациями, фальшивомонетничеством. Криминал в регионе достиг невиданных масштабов. По отношению к преступным группировкам был предпринят целый ряд действий по физическому воздействию и перекрытию их нелегальных финансовых потоков.

Кроме того, экстремистские организации в республиках Северного Кавказа получали финансовую подпитку и от вполне легально действовавших субъектов экономической деятельности. Поэтому началась работа по выявлению и устранению этих источников. С 2000 г. при Главном оперативном управлении Федеральной Службы налоговой полиции действовал отдел «Т», одной из основных задач которого являлось выявление и перекрытие каналов финансирования боевиков на Северном Кавказе. В целом, ФСНП была проделана большая работа в данном направлении. Уже на 1 января 2001 г. на оперативном учете в ФСНП состояли 4244 юридических и физических лица, подозреваемых в связях с преступным сообществом, террористическими и экстремистскими организациями. Было возбуждено 305 уголовных дел. Непосредственно на территории Южного федерального округа в 2001 г. было проведено 9 межрегиональных операций в сфере топливно-энергетического комплекса, оборота алкогольной продукции и внешнеэкономической деятельности. Десятки предприятий, чья собственность и экономическая деятельность, была так или иначе связана с экстремистскими организациями, были ликвидированы, а лица, причастные к незаконной деятельности, арестованы.

В течение двух недель после завершения контртеррористической операции в сентябре 1999 г. в Дагестане следственный отдел Управления ФСБ по Республике Дагестан завершил ряд уголовных дел, связанных с незаконными вооруженными формированиями. Уголовные дела были возбуждены в отношении лиц, связанных с вооруженными экстремистскими организациями, в частности, последователей ваххабизма' из числа жителей Магарамкентского района и сел Карамахи и Чабанмахи Буйнакского района Дагестана, участвовавших в антиконституционном мятеже в период вторжения бандформирований и причастных к организации лагерей подготовки диверсантов. В течение года после завершения контртеррористической операции прокуратурой РД было привлечено к уголовной ответственности за участие в незаконных вооруженных формированиях, причастность к террористическим акциям, пособничество экстремистам более 320 лиц. Ею было объявлено в розыск 69 лиц, в том числе, санкционированы аресты и объявлены в международный розыск такие террористы, как Хаттаб, Шамиль и Ширвани Басаевы, Мовлади Удугов

1 Ваххабизм - идеология наиболее радикального течения в исламе. Последователи данного течения не признают данного названия и называют себя «салафитами». 
и другие, осуществлявшие подготовку и непосредственно участвовавших в нападениях на населенные пункты Дагестана [7, с. 25-26].

Около 200 участников незаконных вооруженных формирований были привлечены к суду по обвинению в организации террористического акта в г. Буйнакске 4 сентября 1999 г., в результате которого погибли 64 человека и более 100 человек получили ранения. Суд установил, что заказчиком теракта был один из руководителей международных бандформирований Хаттаб. Уголовное дело в отношении 6 лиц - исполнителей и организаторов террористического акта было направлено в Верховный суд Республики Дагестан. Экс-прокурор республики И. Яралиев отмечал, что впервые в новейшей истории РФ преступления, совершенные в августе - сентябре 1999 г., квалифицировались как организация и участие в вооруженном мятеже [7, с. 30]. За сравнительно короткое время правоохранительными органами были задержаны либо ликвидированы такие одиозные главари бандформирований, как Хасбулат Хасбулатов, МагомедХабиб Магомедов и другие.

Наряду с силовым и правовым противостоянием экстремизму руководство Российской Федерации и Республики Дагестан усилило работу в направлении информационного противостояния. Еще в период нападения и борьбы с бандформированиями в республике в августе 1999 г. был создан Координационный центр для организации идеологического обеспечения информации, освещаемой республиканскими СМИ в плане объективности и оперативности. 18 августа 1999 г. Государственный Совет РД принял постановление «Об идеологической и информационной работе Координационного центра по информационному обеспечению», в котором центру предлагалось улучшить работу по взаимодействию с центральными и республиканскими средствами массовой информации и проведении единой, согласованной информационной политики в освещении происходящих событий в Дагестане. В постановлении также акцентировалось внимание на широком освещении готовности дагестанских народов дать решительный отпор агрессивным планам бандитских формирований, вторгшихся на территорию республики и на ведении систематической работы по разоблачению дезинформации, осуществляемых враждебными Дагестану силами [8]. Это было важное постановление, так как экстремисты, помимо боевых операций, активизировали и информационную борьбу с целью обеспечения международной и внутрироссийской поддержки своих преступлений. Для этого идеологом экстремистов Удуговым было создано информационное агентство «Кавказ центр» и открыт одноименный сайт в сети Интернет. Это агентство распространяло заведомо ложную информацию о мнимых успехах боевиков и высоких потерях федеральных сил с целью сформировать у мировой общественности и ру- ководства иностранных государств негативное отношение к России. В этой информационной войне использовалось более 100 финансируемых террористами сайтов на русском, английском, арабском, французском и других языках. Информационные центры террористов были созданы в Грузии, Азербайджане, Украине, Финляндии, Турции и Польше с целью создания искаженного представления в общественном сознании Запада действий федеральных сил, представляя их как «зверства русских солдат в отношении мирного населения». В этих условиях одной из важнейших задач являлось обеспечение информационной безопасности республики и противодействия насаждению здесь радикальных религиозных течений. О результативности работы СМИ РД говорил министр по национальной политике и внешним связям РД М.-С. Гусаев 31 августа 1999 г. на заседании Государственного Совета РД при обсуждении ситуации в селениях Карамахи и Чабанмахи. Он высоко оценил работу по достоверному и оперативному освещению происходящих событий большинством СМИ республики, отметив, что за август 1999 года весь мир во многом пересмотрел свое отношение к Дагестану [6, с. 181]. По предложению министерства для противостояния экстремизму активизировалась работа в направлении просвещения граждан в сфере культурного и конфессионального образования. Упор делался на культивировании в молодежной среде таких гуманистических ценностей, как толерантность и терпимость.

Действия федеральных и региональных структур не ограничивались лишь карательными мерами, а являлись лишь частью программы по борьбе с терроризмом и возвращению республики в правовое и хозяйственное поле России. Правительство России во главе с В. Путиным, проявляя заботу о Дагестане, приняло 22 сентября 1999 г. распоряжение «О ликвидации последствий террористических актов в Ботлихском и Цумадинском районах Республики Дагестан в августе 1999 г.» [9]. Согласно ему поручалось выделить из резервного фонда Правительства РФ правительству РД 339, 5 млн. рублей на компенсационные выплат населению за разрушенное и поврежденное жильё, утраченное имущество и выплаты за погибших членов семей и нанесенный ущерб здоровью пострадавших граждан. МЧС России выделило республике 9 млн. рублей на оплату продовольствия, материально-технических ресурсов и их доставку в Дагестан; Фонд медицинского страхования выделил 19, 7 млн. рублей на оплату временного проживания и питания пострадавших граждан. Распоряжением также предусматривалось за счет средств, выделяемых Минфином России в размере 42, 4 млн. рублей, осуществить аварийно-восстановительные работы на объектах социальной сферы, коммунального хозяйства, энергетики, связи и транспорта, пострадавших в результате террористических акций [9]. В целях стабилизации ситуации в Дагестане и в регионе в целом Федеральный центр направил 
существенные инвестиции в энергетическую отрасль республики. Общие капиталовложения в Ирганайскую ГЭС на территории РД составили 65\%. Был ускоренно введен первый гидроагрегат Ирганайской ГЭС, что позволило получить годовую выработку электроэнергии в 450 млн. кВТ-ч. В результате только на одном промышленном объекте было создано 650 рабочих мест [10, с. 4]. Инвестиции федерального центра в РД стали довольно быстро давать положительный результат, выразившийся в 2001 г. в увеличении объема промышленной продукции по сравнению с предыдущим годом на 23 \%, сельского хозяйства - на 21 \%. «...Положительное сальдо внешнеторгового баланса в РД составило 48, 3 млн. рублей, что выше уровня 2000 года в 6,9 раза» [11, с. 1].

Следует отметить, что события 1999 г. в Дагестане вскрыли очень серьезные проблемы не только в кавказской политике Российского государства, но в целом политического устройства самой Федерации, которая после распада Советского Союза так и не сумела к тому времени стать полноценным и эффективным политическим и экономическим механизмом. Государству предстояло сформировать системную политику во всех сферах политической, правовой и культурной жизни страны. Приход к власти в 2000 г. новой команды во главе с В. Путиным способствовал созданию новых отношений между федеральным центром и регионами, а также формированию новой модели политики на Северном Кавказе. Чрезвычайно важным событием стало создание Южного федерального округа, направленного на формирование эффективной вертикали власти, стабильной политической системы. Полномочные представители Президента РФ в Южном федеральном округе и его аппарат были призваны улучшить взаимодействие Центра и регионов. Одновременно были сформированы такие важные структуры как совет старейшин, консультативный совет, координационный совет по казачеству, призванные помочь государственной власти в вопросах разработки эффективных механизмов развития северокавказского региона, выработке программ предотвращения межконфессиональных и межэтнических конфликтов. Создание новых политических структур и привлечение общественности к решению сложных социальных вопросов позволило ликвидировать противоречия между Конституцией РФ, федеральным законодательством и законодательством субъектов российской федерации на Северном Кавказе. Это, в свою очередь, способствовало укреплению государственности в РФ и предотвращению возможных проявлений ущемления прав и свобод на всей территории РФ. [12, с. 111-112].

Формирование эффективных механизмов борьбы с экстремизмом являлось важнейшим составляющим новой политической стратегии и тактики федерального центра в северокавказском регионе. Среди комплекса мер, необходимых решить на Северном Кавказе, пробле- ма ваххабизма - наиболее радикального течения в исламе, была первоочередной. Ваххабизм пустил глубокие корни в регионе, насчитывавшем на 1 января 1999 г. 4 млн. человек, исповедовавших ислам. К 1999 г. в ряде сел Буйнакского района РД, существовали так называемые «независимые исламские территории», где не работали российские законы. Руководство РФ приступило к выработке адекватной стратегии и тактики действий в этом сложном регионе, причем действовать приходилось чрезвычайно осторожно, чтобы не задеть религиозные чувства мусульман, исповедовавших традиционный ислам. Подавляющее большинство местного населения, в том числе духовенство, поддержало федеральные власти в ее действиях по ликвидации ваххабитского подполья. Пользуясь поддержкой федерального центра и местного населения, региональные власти совместно с правоохранительными структурами перешли к энергичному применению административных ресурсов для подавления экстремистских организаций. Реализации новой стратегии и тактики властей призваны были обеспечить вновь созданные в республиках Северного Кавказа специальные оперативные группы, осуществлявшие профилактические и оперативные мероприятия по выявлению и пресечению экстремистской деятельности. Руководители экстремистов арестовывались либо уничтожались в случае оказания сопротивления при аресте, агитационный материал ваххабитского содержания изымался, учебные заведения с экстремистским уклоном закрывались, усилена была профилактическая работа. Таким образом, правоохранительные органы методично реализовывали поставленную перед ними задачу - купирование проявлений экстремизма и терроризма.

Важное значение в условиях широкомасштабных антитеррористических мероприятий, проводимых на юге страны, имел Федеральный закон «О противодействии экстремистской деятельности», принятый 25 июля 2002 года [13]. Закон дал определение понятиям экстремистская деятельность, экстремистская организация и экстремистские материалы, определил основные принципы и направления противодействия экстремистской деятельности. Таким образом, в результате принятия федерального закона была создана правовая база для противодействия экстремизму на территории РФ, которая лишала экстремистов возможности в завуалированной или открытой форме осуществлять свою антиконституционную деятельность.

Следует отметить, что после разгрома бандформирований в Дагестане в 1999 г., работа правоохранительных органов только увеличилась, поскольку экстремисты перешли в подполье и развернули по стране масштабную террористическую деятельность. 9 мая 2002 г. бандподполье устроило теракт в дагестанском городе Каспийске во время парада Победы, в результате которого пострадали гражданские лица, в том числе дети. В это 
время на территории Дагестана действовало подпольное террористическое объединение «Джамаат Шариат», известное еще как «Вилаят Дагестан», ставившее своей целью отделение Дагестана от России. «Вилаят Дагестан» входил в состав Имарата Кавказа - террористической организации, ставившей целью создания на территории Северного Кавказа исламского государства. Террористические акты этой группировки отличались дерзостью и бесчеловечностью. Правоохранительные органы методично уничтожали главарей и непримиримых рядовых членов этой организации.

В такой ситуации в июле 2003 г. президент РФ В. Путин подписал Указ «О дополнительных мерах по борьбе с терроризмом на территории Северо-Кавказского региона Российской Федерации», который предусматривал совершенствование государственной антитеррористической системы. Значительная часть полномочий в антитеррористической деятельности была передана от военных комендатур к местным структурам МВД. Это стало возможным с завершением открытой военной стадии контртеррористической операции на территории соседней с Дагестаном Республики Ичкерия, которая завершилась разгромом крупных бандформирований. Последней войсковой операцией на Северном Кавказе, по сути, стал разгром в конце 2003 - начале 2004 гг. бандформирования, возглавляемого полевым командиром Русланом Гелаевым. Решительные действия российских правоохранительных органов и готовность применить самые радикальные действия по защите своих национальных интересов и безопасности государства заставили задуматься, в том числе, зарубежных спонсоров северокавказских бандформирований из числа мусульманских стран Ближнего Востока. В какой-то степени отрезвляюще на них подействовала спецоперация российских спецслужб по ликвидации одного из главарей боевиков 3. Яндарбиева в центре столицы Катара городе Дохе. После этого резко снижаются объемы финансовой помощи вооруженным формированиям Северного Кавказа со стороны этих государств.

Карательные меры не могли быть универсальным средством решения проблем терроризма в республике, поэтому наряду с решением социально-экономических проблем в Дагестане предстояло осуществить масштабные мероприятия на идеологическом фронте с тем, чтобы не позволить экстремистам вовлекать молодежь в свою незаконную деятельность. Работа правоохранительных органов координировалась с деятельностью религиозных организаций, исповедовавших традиционный ислам. Религиозные деятели под руководством Духовного управления мусульман Дагестана, как и других северокавказских республик, ревностно относившихся к любым отклонениям и искажениям в сфере религиозной идеологии, активно подключились к процессу «выкорчевывания» из сознания людей экстремистской идеологии. Специалисты Духовного управления мусульман Дагестана помогали дать экспертную оценку с последующим изъятием литературы ваххабитского содержания, которая поступала из ближневосточных стран, множилась на местах и бесплатно распространялась среди молодежи, вовлекая ее в экстремистские организации. Активная миссионерская деятельность духовенства была нацелена на консолидацию народа и возрождение культурно-исторического прошлого и национальных ценностей. Следует отметить, что данная работа строилась на взаимодействии всех заинтересованных сторон - духовенства, федеральных органов власти, органов государственной власти Дагестана, общественных организаций, вузов, школ.

Подводя итоги нашего исследования, отметим, что вторжение международных бандформирований в Дагестан в 1999 г. вынудило федеральные власти применить целый комплекс мер противодействия экстремистским организациям. Борьба силовых структур и государственных органов Российской Федерации и её субъекта Республики Дагестан с терроризмом, нахлынувшим на регион на рубеже веков показал, что добиться положительных результатов можно при сочетании следующих подходов: силовое подавление экстремистских организаций, использование идеологической борьбы светских и духовных структур общества, ликвидация материальной базы террористов и их финансовой поддержки из-за рубежа, работа по совершенствованию законодательной базы борьбы с экстремизмом и терроризмом, экономические меры по развитию республики, проведение взвешенной национальной политики на всем пространстве Северного Кавказа. Все указанные подходы для стабилизации ситуации в Дагестане дали свои результаты. Несмотря на то, что преждевременно говорить о полной ликвидации террористических угроз в Дагестане и в регионе в целом, все же обоснованно можно утверждать, что в результате комплексной работы всех правоохранительных, налоговых и прочих государственных структур удалось победить бандподполье, перемолоть ядро террористических группировок и взять ситуацию под контроль.

1. Бочарников И.В. Пути преодоления террористической угрозы в Южном Федеральном округе //Аналитический вестник. №27(247). Сентябрь 2004. С. $36-52$. 
2. 0 запрете ваххабитской и иной экстремистской деятельности на территории Республики Дагестан: закон: [принят Народным собранием Республики Дагестан 16 сентября 1999 г.: одобрен Председателем Государственного Совета РД М. Магомедовым 22 сентября 1999 г.]. [Электронный ресурс]: - URL: http://docs.cntd.ru/document/802037545

3. 0 ситуации в Республике Дагестан, первоочередных мерах по обеспечению национальной безопасности Российской Федерации и борьбе с терроризмом». [Электронный ресурс]: Постановление Государственной Думы Федерального Собрания РФ от 15 сентября 1999 г. - URL: http://pravo.gov.ru/proxy/ip $\mathrm{s} /$ ?docbody $=\&$ prevDoc $=102013812 \&$ backlink $=1 \&$ nd $=102061736 \& \mathrm{rdk}$

4. Взрывая дома наших сограждан, бандиты взрывают государство: Полная стенограмма выступления Владимира Путина перед депутатами Государственной Думы Федерального Собрания РФ от 15 сентября 1999 г. //Газета Коммерсант. № 167 от 15.09.1999 г. [Электронный pecypc] - URL: https://www. kommersant.ru/doc/225573

5. Паненков А.А. Борьба с финансированием террористической деятельности //Право и безопасность. № 3.(32). Октябрь 2009. [Электронный ресурс] - URL: http://dpr.ru/pravo/pravo_28_16.htm

6. Гаджиев Р. Час испытаний. Хроника военных действий в Дагестане. Август-сентябрь 1999 года. Часть 1. - Махачкала, 2000.

7. Яралиев И.М. Религиозный экстремизм как форма международного терроризма //Религиозный фактор в жизни современного дагестанского общества: материалы Республиканской научно-практической конференции. - Махачкала, 2002.

8. Постановление Государственного Совета РД «0б идеологической и информационной работе Координационного центра по информационному обеспечению»// Собрание законодательства РФ. [Электронный ресурс] - URL: http://dagestan.regnews.org/doc/iq|60.htm

9. Распоряжение Правительства РФ № 1499-р от 22 сентября 1999 г. [Электронный ресурc] -URL: http//www.law7.ru/base74/part7/d74ru7397.htm

10. Лунев Э. Дагестан уходит в энергетический отрыв //Парламентская газета. 2001. 20 декабря.

11. Выступление Председателя Правительства РД Шихсаидова Х.И. на XXV сессии НС РД второго созыва 25 декабря 2001 г. «0 ходе выполнении инвестиционных программ социально-экономического развития РД в 2001 году и мероприятиях, намеченных на 2002 г.». //Дагестанская правда. 2001. 26 декабря.

12. Васильева 0.А. Роль федеральных округов в совершенствовании механизма политического управления на Кавказе //Каспийский регион: политика, экономика, культура. 2010. № 3. С. 112-122.

13. 0 противодействии экстремистской деятельности (с изменениями и дополнениями): Федеральный закон от 25 июля 2002 г. N $114-$ Ф3 [Электронный ресурc] - http://base.garant.ru/12127578/\#ixzz6KdQ4hyrZ

() Далгат Фатима Магомедовна (dalgat63@mail.ru).

Журнал «Современная наука: актуальные проблемы теории и практики»

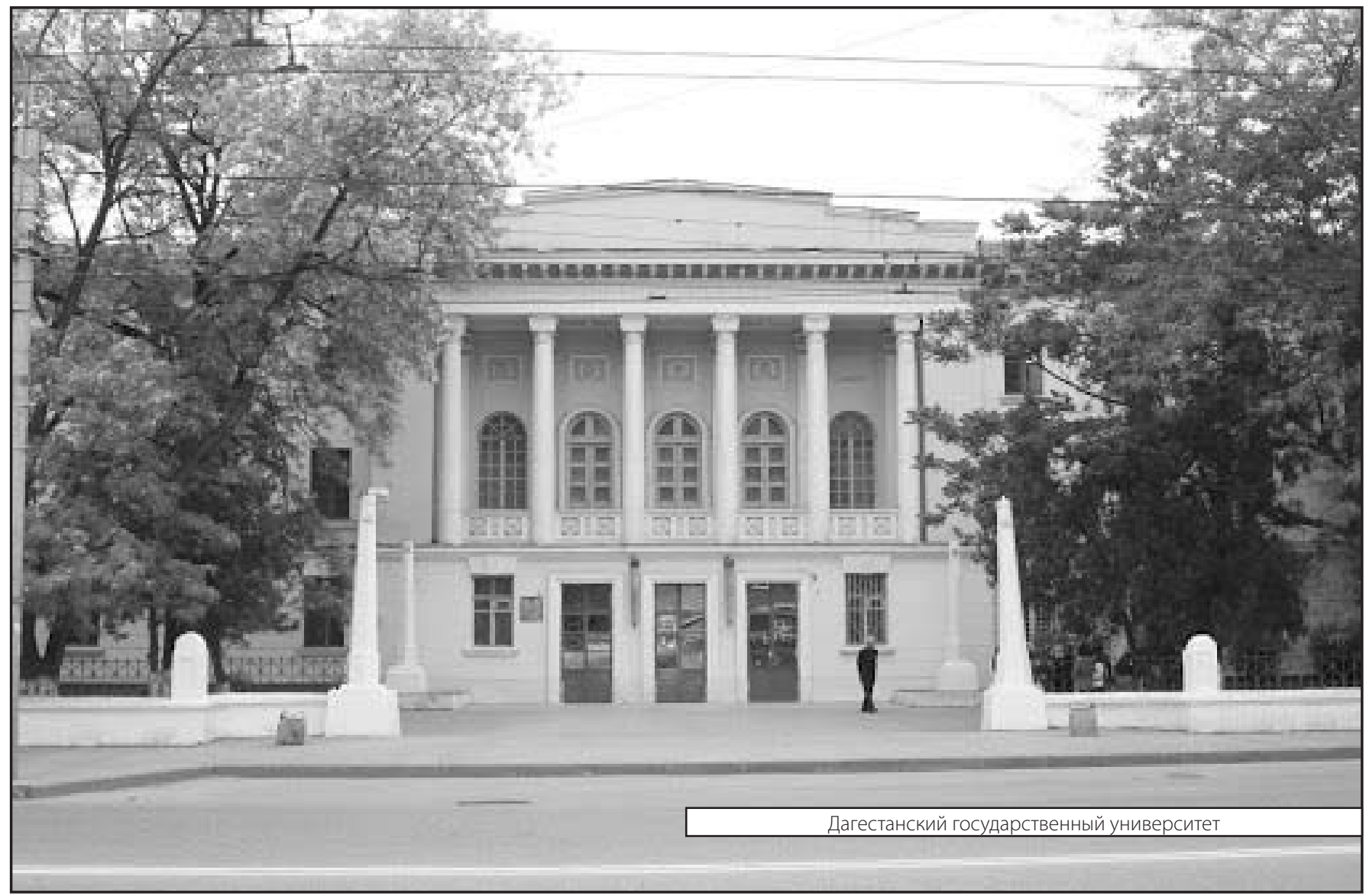

